\title{
George Papanicolaou's Efforts to Develop Novel Cytologic Methods for the Early Diagnosis of Endometrial Carcinoma
}

\author{
R. Marshall Austin \\ Department of Pathology, Magee-Womens Hospital of the University of Pittsburgh Medical Center, Pittsburgh, PA, USA
}

\section{Keywords}

Papanicolaou · Endometrial explants · Endometrial cytology

\section{Abstract}

Toward the end of his career, Dr. George Papanicolaou became interested in human endometrial explants placed into tissue culture. The initial focus of his studies was on phagocytic cells emanating from endometrial explants and their role in cleansing the uterine cavity after each menstrual cycle and in sterilizing the uterine cavity in the face of infection. Papanicolaou also observed that growth rates of explanted normal and pathologic endometrial tissues differed considerably. Explants of endometrial malignancies exhibited not only increased growth rates but also visible proliferation of cells with readily identifiable cytologic features of malignancy. Acknowledging that cytologic screening for early diagnosis of intrauterine malignancies had up to that point not proven to be reliable as screening for cervical cancer, he hoped that the tissue culture explant technique could prove to be a new adjunctive diagnostic method for the diagnosis of endometrial and other female genital tract malignancies not readily detectible by other diagnostic procedures. Papanicolaou's untimely death in 1962 cut short his progress in this area of study.

(c) 2017 S. Karger AG, Base

The article "Diagnostic Value of Cells of Endometrial and Ovarian Origin in Human Tissue Cultures" was published in 1961, near the end of Papanicolaou's remarkable career [1]. In November of that year Papanicolaou moved at the age of 78 years to Miami, FL, USA, hoping to realize his longstanding dream of setting up the Papanicolaou Research Cancer Institute at the University of Miami. Unfortunately, he died unexpectedly of a heart attack in February 1962, three months before the dedication of the institute in May 1962 [2].

Papanicolaou's interest in human endometrial explants placed into tissue culture can be traced back to other articles he published between 1953 and 1961 [3-6]. Papanicolaou acknowledges carrying out "a six-year study

\section{KARGER}

(c) 2017 S. Karger AG, Basel

E-Mail karger@karger.com

www.karger.com/acy
Correspondence to: Prof. R. Marshall Austin

Gynecologic Pathology Division, Department of Pathology

Magee-Womens Hospital of the University of Pittsburgh Medical Center, 300 Halket Street Pittsburgh, PA 15213 (USA)

E-Mail raustin@magee.edu 
on the behavior and the potentialities for differentiation and growth of normal, benign, and malignant endometrial cells" in tissue cultures [6]. The initial focus of his studies was on phagocytic cells emanating from endometrial explants and their role in cleansing the uterine cavity after each menstrual cycle and in sterilizing the uterine cavity in the face of infection [3]. Later, in Papanicolaou's characteristically meticulous and step-by-step investigational manner, he extended these early studies to include normal endometria from different phases of the menstrual cycle, endometrial tissues representing nonmalignant pathologic states, and explants of specific endometrial malignancies $[4,5]$. In explants of normal endometrium, the highest growth rates were observed during the proliferative phase. Increased growth rates were also documented in explants of endometrial polyps and hyperplasias. Explants of malignancies, however, exhibited not only increased growth rates but also visible proliferation of cells with identifiable cytologic nuclear features of malignancy [4-6].

The initial publication of Papanicolaou and Traut [7] on the diagnostic value of vaginal smears in carcinoma of the uterus illustrated diagnostic samples of both carcinoma of the cervix and carcinoma of the uterus. The range of cytologic findings associated with both cervical carcinomas and endometrial carcinomas was further expanded in their 1943 monograph [8]. Hopes were initially high that "incipient phases" of both diseases would often prove to be detectible by cytology [7]. By the time of the 1961 Acta Cytologica article, however, Papanicolaou had acknowledged that "cytology, which proved to be of major importance in the diagnosis and early detection of cancer of the uterine cervix, has unfortunately, not been equally satisfactory in the detection of intra-uterine malignancies" [1]. Using the tissue culture explant technique, the investigators found that "the individual characteristics of the malignant cells and their growth patterns... are, in many cases very clearly defined. A conclusive and definitely positive diagnosis, equivalent to a Class V cytologic evaluation is thus possible in a fair number of cases" [1]. The authors concluded that the tissue culture method could prove to be an adjunctive diagnostic method for "cases in which the presence of a malignant neoplasm could not be established by other diagnostic procedures" [1]. Unfortunately, these developmental studies by Papanicolaou and his technical assistant, Frances V. Maddi, do not appear to have been continued by other investigators after Papanicolaou's move to Miami and death in early 1962. Despite the later development of the Tao Brush for obtaining endometrial cytology samples, to the present day no cytologic method has gained widespread acceptance as a reliable screening method for the early detection of endometrial carcinoma [9].

\section{Disclosure Statement}

The author has no conflicts of interest to declare. 


\title{
A G T A G Y T O L O G I G A
}

Vol. 5

January-February 1961

No. 1

\section{Diagnostic Value of Cells of Endometrial and Ovarian Origin in Human Tissue Cultures. *}

\author{
George N. Papanicolaot, M.D., Ph.D., Frances V. Maddi, B.A. \\ From the Papanicolaon Research Laboratory, Department of Anatomy). \\ Comell University Medical College, NewU York, U.S.A.
}

THE OBSERVATIONS reported here were made during a six-year study on the behavior and the potentialities. for clifferentiation and growth of normal, benign and malignant endometrial cells in tissue cultures. Material was obtained by aspiration and during curettage or hysterectomy. The findings in these examinations and a detailed description of the technics used were published in previous papers. ${ }^{3.4}$ The salient points may be summarized as follows:

1. Growth activity was observed in both epithelial and stromal cells during all phases of the normal menstrual cycle.

2. Both types of cells exhibited phagocytic action and showed a tendency to adhere to and follow the pathways of cotton or other fibers experimentally introduced into the cultures. However, each of the two cell types behaved differently: the stromal swarmed around the fibers in large numbers and assumed a pattern suggesting group phagocytosis, as if trying to dispose

* This work has been aided by a grant from the American Cancer Socicty, Inc., New York, N. Y. of these foreign elements, while the epithelial cells glided around the fibers in a single layer and in a regular fashion just as the normal epithelial cells do as they spread over the endometrium's naked surface in order to form a new epithelial lining at the end of each menstrual phase (Fig. 1, 2). It is thus evident that the differentiation and growth of the endometrial cclls in vitro are governed largely by intrinsic factors which differ in each of the two cells types.

3. Ciliated epithelial cells were observed in a fair number of living cultures with the ciliary activity continuing for a period of three to ten days. Their presence was noted chiefly in cases of polypoid hyperplasia or benign endometrial polyps.

4. Explants from benign polyps or malignant neoplasms of the endometrium displayed very active growth in vitro. In the normal, the highest rate of growth was observed during the proliferative phase of the menstrual cycle.

5. In contrast to the normal cells or to those of benign polyps, the cells growing out of malignant explants exhibited 


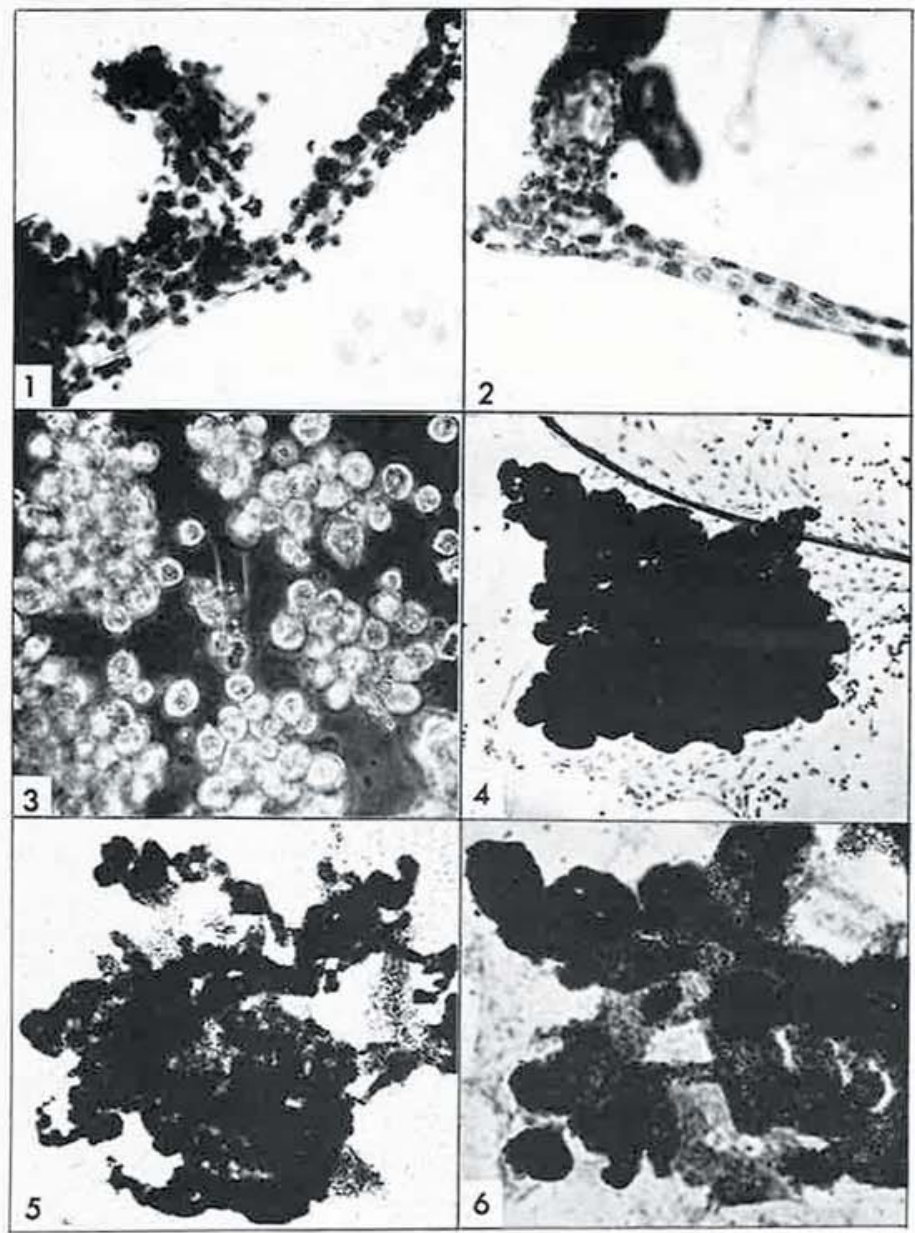

Fic. 1. 3-day endometrial tissue culture demonstrating swarming of stromal cells around cotton libers (x240). Fic. 2.4 . day endometrial tissuc culture demonstrating migration of epithclial cclls around cotton fibers 240). FIG. 3. 8-clay living tissue culture of an adenocarcinoma of the endometrium demonstratin? direct growth pattern with detached cell clusters forming new centers of growth $(x 240)$. Fis. 4. 48. hour endometrial tissuc culture demonstrating $\mathrm{di}$ rect epithelial growth pattcrn of a normal explant corresponding to the seventh day of the menstrual cycle (x60). Fic. 5, 5-day tissue culture of a benign endometrial polyp show. ing direct epithelial growth pattern $(\mathrm{x} 60)$. Fic. 6. 3-day tissue culture of an adenocarcinoma of the endometrium exhibiting direct epithclial growth pattern $(x 60)$.

marked structural abnormalities, such as a notable variation in the size of the cells and of their nuclei, a richer chromatin content and an increased mitotic and phagocytic activity.

6. The identification of malignant cells appears to be somewhat easier and more dependable in tissue cultures than in cytologic smears because of the absence of degenerated and distorted cell forms, which often cause false-positive evaluations in smears. Since cellular growth may appear in a tissue culture within 16 to 48 hours, the study of the behavior of the cells in vitro may be very helpful in cases in which no definite diagnosis can be established through the use of other methods.

The usefulness of the tissue culture method in the diagnosis of cancer has been further investigated in two groups of patients: one, consisting of 50 cases with pathologically proven adenocarcinoma of the enclometrium, and another, of 25 cases of peritoneal and pleural effusions or washings from proven adenocarcinoma of the ovary. 


\section{Material}

The material used in this investigation was obtained largely from the Lying-In Hospital of Cornell Medical Center and, to a lesser extent, from Bellevue Hospital, French Hospital and Memorial Hospital. It consisted of human endometrial tissue obtained by aspiration, curettage or hysterectomy and of peritoneal fluid and washings aspirated during operations. $†$

The technics used for processing this material and preparing the tissue cultures have been somewhat different from those used in the earlier studies. A description of these was given in our first publication. The most important departure has been the additional use of the roller tube technic, which proved to be particularly suitable in the application of this method in cancer diagnosis.

The general procedures followed in this study were as follows: the endometrial aspiration, which consisted for the most part of tissue fragments and loose cells, was placed in a small sterile jar containing tyrode solution. The celis may be kept in this solution for a number of hours, if necessary. Sodium penicillin and streptomycin calcium chloride were added to give a final concentration of 250 units of each per cubic centimeter, though many of our experiments have been carried out without the use of antibiotics. The inherent sterile condition of the endometrium adds to the practicability of this technic.

+ The authors wish to cxpress their gratitude to Dr. R. Gordon Douglas and his Staff for their kind cooperation in making available to us material from patients of the Lying-In Hospital and to Dr. Elmer Kramer for placing at our disposal pathology sec. Kramer for placing at our disposal pathology sec-
tions with which we were able to correlate our findings. We also wish to express our appreciation to Dr. Mortimer Speiser and Dr. Crril Solomon of French Hospital and to Dr. Gordon W. Douglas, Director of the Gynecology Division of the Bellevue Hospital. In addition, we wish to thank $\mathrm{Mr}$. Constantine Railey for his valuable assistance in the selection and preparation of the photomicrographs as well as to Miss Joan Farrell for her assistance in the preparation of this manuscript.
The loose cells and tissue fragments are implanted on $22 \times 11$ rectangular squares in a medium consisting of two drops of: one part fowl plasma, one part 50 per cent embryo extract and three parts human placental cord serum. The culture is allowed to clot and adhere to the coverslip) before one $c c$. of a 50 per cent embryo extract and three parts of human cord serum are added. Within 16 to 24 hours there is, as a rule, growth of endometrial cells. The rectangular square is then removed aseptically and placed in a staining dish containing ether-alcohol fixative. Most of our cultures were stained with hematoxylin and counterstained with Orange-G. This whole procedure requires approximately 45 minutes. If the endometrial aspiration is very cellular another coverslip may be inserted into the same roller tube. Additional cultures for continued periodic examinations may thus be obtained.

In a simple endometrial aspiration, when properly obtained, as many as eight to ten roller tubes may be set up and about six Maximow cultures. If the material is abundant, it is advisable to prepare as many cultures as possible, particularly in the doubtful cases. Peritoneal effusions and washings have also been cultured in roller tubes using the same technic. When the fluid is very cellular, the specimen, instead of being centrifugated, may be left standing for awhile. One cc. of the sediment, which collects at the bottom of the receptacle, plus one cc. of the effusion fluid as a culture medium has rendered excellent results. In cultures prepared in this way, growth has been evident within 16 to 24 hours. In the preparation of Maximow cultures, centrifugation of the fluid is advisable. With regard to pleural or peritoneal washings, a mixture of half the washing, if cellular, and half of the regular meclium used for the endometrial cultures has also proved successful. Cultures from effusions may retain their viability for as 


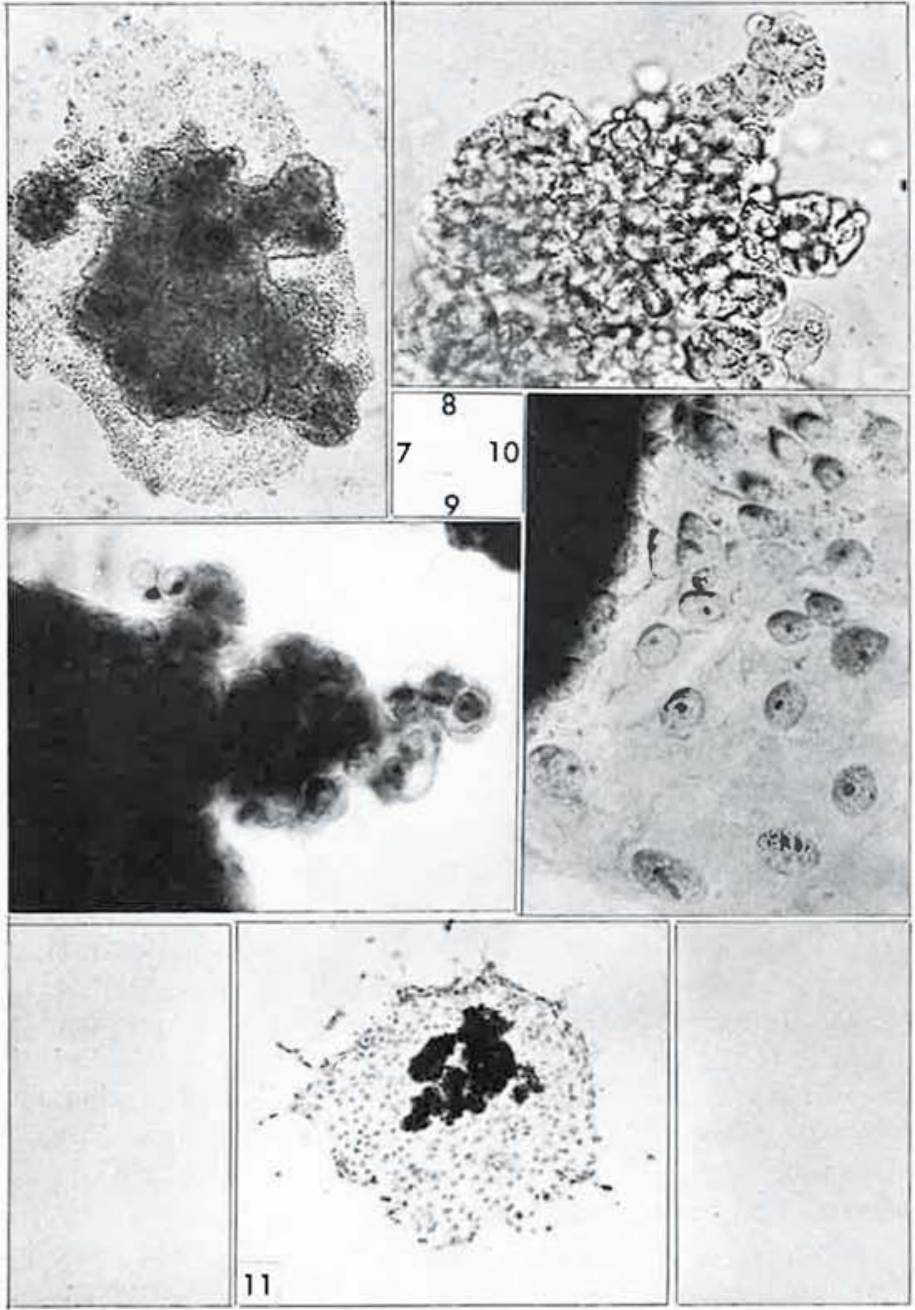

Fitc. 7. 7-day living c11. dometrial tissue culture of a case diagnosed pathologically as an carly actchocarcinoma of the $\mathrm{cll}$ dometrium demonstrating a direct growth pattern in the form of roundicl protrusions and an outtrowth forming a sheath of flattened cells ( $\times 60)$. Specimen obtained by endometrial aspiration. FIG. 8. Another 7-day tissue culture from the same case as above showing direct growth pattern ( $\mathrm{x}$ 230). Fic. 9. 4-day tissue culture of an adenocar. cinoma of the endometrium showing a direct growth pattern $(x 460)$. Fic. 10. Same culture as above demonstrating outgrowth of cells from the same malignant explant same malignant explant
$(\mathrm{x} 460)$. FI. I1. 63-hour tissue culture of an adenocarcinoma of the endometrium illustrating an aggregate of cells emanating from a central core of densely pacied cells (x60).

long as 30 days, without change of medium.

Liquefaction of the medium is not an uncommon occurrence in tissue cultures of the endometrium. Inactivation of the human cord serum has helped to eliminate this reaction to a certain degree. Another type of medium,* which has been tried

- One part of a mixture of 50 per cent chick embryo extract and 50 per cent beef amniotic extract and three parts of a mixture of 50 per cent human placental (cord) serum and 50 per cent of basal medium (Eagle). . experimentally, appears to be rather promising since it permits the tissue fragments to be kept intact after washing, thereby preserving undisturbed the structural pattern of the cellular outgrowth of the explant.

\section{Comparative Value of the Maximow} and Roller Tube Technics

Although extensive use of the roller tube technic was made in this study, it was found that much could be gained by a 
parallel use of the Maximow technic. Each has, apparently, certain advantages over the other. In the roller tube technic, there is less detail involved in the maintenance and preservation of the cells. Furthermore, little or no change of the medium is necessary and definite results are obtainable within a relatively short period of time.
Therefore, many more specimens may be available for study. Another significant point is that the cultures may be left unclisturbed for a longer period of time, as many as ten days, without any appreciable deterioration. However, since a number of cell clusters or aggregates adhere to the rounded wall of the roller tube, their ex-

Fic. 12. Norinal epithelial sheath cells from a 4-day endometrial tissue culture corresponding to the 8 th day of the menstrual cycle ( $\mathrm{x} 165)$. Fig. 13. Sheath cells from a 7 day tissue culture of an adenocarcinoma of the endometrium ( $\mathrm{4} 465$ ). Note large nucleoli. Fic. 14. Sheatb cells from a 5-day tissue culture of a papil. lary adenocarcinoma of the cndometrium ( $\times 465)$. Note markedly abmormal nuclei Frc. 15. Sheath cells from a 5-day tissue culturc of an adenocarcinoma of the endome. trium ( $x 465)$. Note phagocytosis of degenerating inflammatory cells and prominent nucleoli. FIG. 16. Normal stromal cells from a 48-hour endometrial tissue culture ( 4465$)$. Compare with Fig. 2, which shows normal cpithelial colls. Fig. 17 Sheath cells from a 12-day tissue culture of a carcinosarcoma of the endo. metrium (x465). Note nuclear abnormalities, mitosis and phagocytic activity. Specimen obtained by endometrial aspiration.

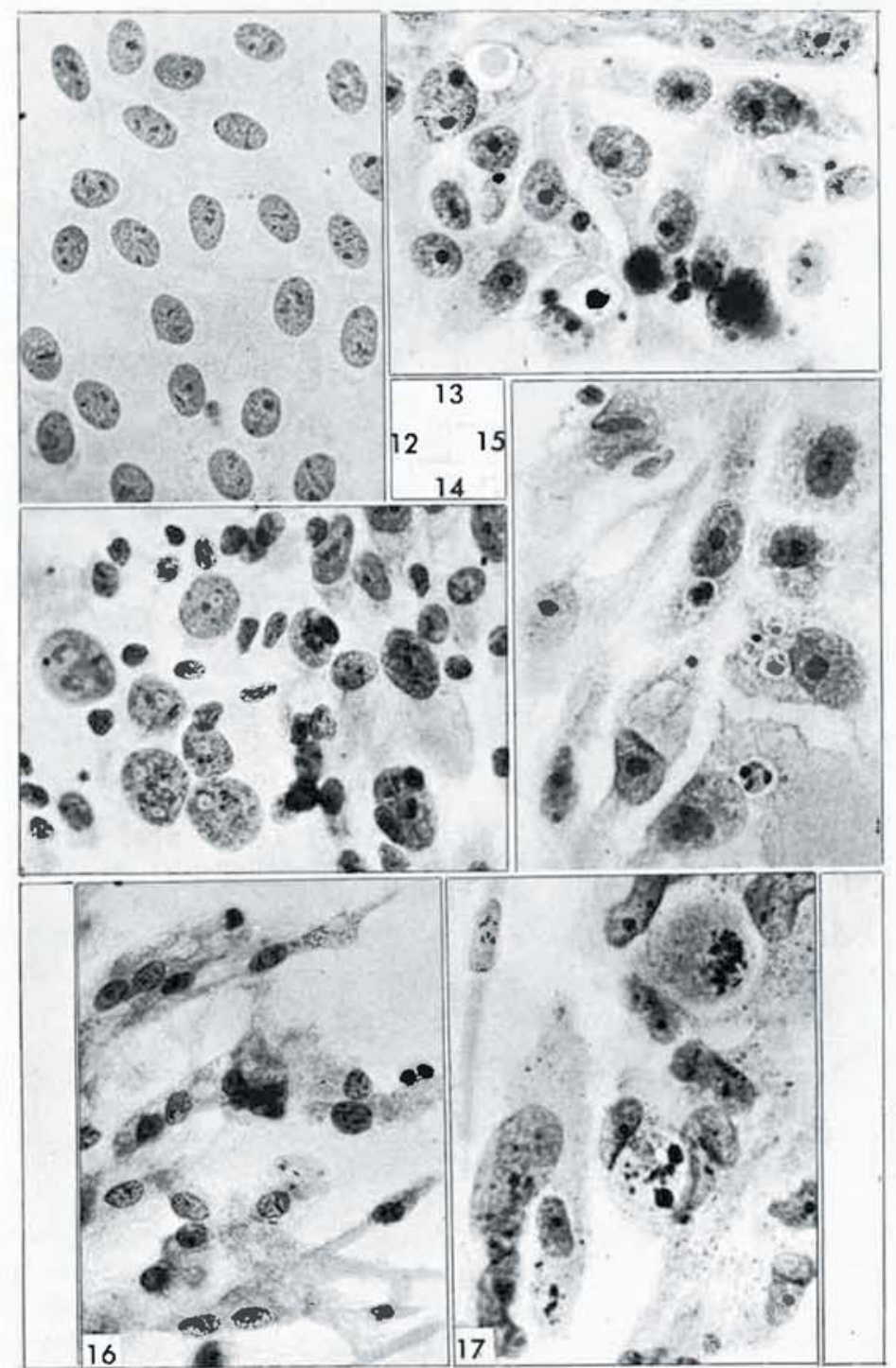




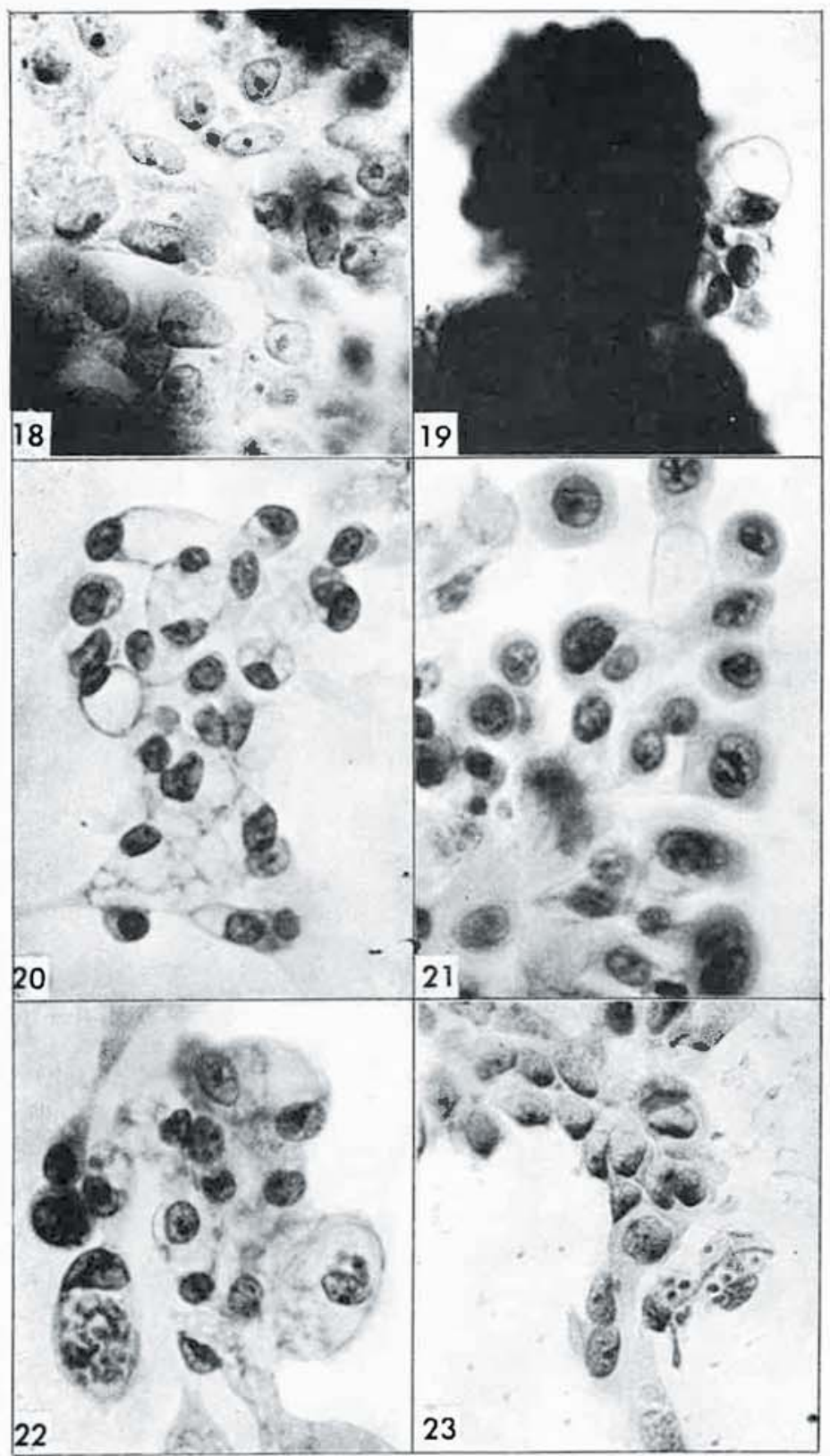

Fic. 18, Sheath cells from a 7 -day tissue culture of an adenocarcinoma of the endometrium. Same case as in Fig. 13 ( $\times 540)$. Note large nucleoli and polaization of the nuclear chromatin. Fig. 19 6-day tissue culture of an adenocarcinoma of the endometrium $(\times 540)$. Note vacuolated cells breaking away from a growing ex plant. Fic. 20. 3-day tissue culture of an adcnocatcinoma of the endometrium showing generalized vacuolation (x540). Fig. 21. 20-hour roller tube tissuc culture of peritoneal washings from a case of a papillary serous cystadenocarcinoma of the ovary $(x 540)$. Note squamous metaplasia as seen in cells of the adenoacanthoma type. Fic. 22.16 . hour roller tube tissue culture of an adenocar cinoma of the endometrium. Specimen obtained by endometrial aspiration (x540). Note vacuolation and phagocytosis of detritus. Fic. 23. 48-hour jar tissue culture of an adeno. carcinoma of the endo. metrium (x540). Note phagocytosis of monilia spores and a mycelium by adenocarcinoma cells.

amination or photography under higher magnifications becomes difficult.

The Maximow culture, although in a way more involved in its preparation and maintenance, permits a more comprehensive study of both the living explant and the fixed and stained specimen. One can thus better evaluate the general con- 
figuration and structural pattern of the explant and its growth potential. On the other hand, the roller tube culture lends itself better to use as a routine diagnostic test. A combination of the two, whenever possible, is, therefore, very desirable.

\section{Cytology of Tissue Cultures in Adeno-} carcinomas of the Endometrium

A general description of the normal and malignant cytology of the endometrial mucosa, as seen in fixed and stained tissue cultures, can be found in our previous papers. The description given here, though supplementary, is, however, more specific as it covers in sreater detail the diagnostic aspects and potentialities of the tissue cultire technic.

In examining a culture of malignant endometrial cells, one is always impressed with their high growth activity. In the unclisturbed living culture, there is, as a rule, continual outgrowth of cells, many of which become detached from the surface of the explant either singly or in the form of sheaths, aggregates or clusters of cells. Such cell groups as they move away from the explant may become new centers of expansion and growth (Fig. 3). A more typical picture of this can be seen in the Maximow culture. The growth patterns are essentially the same in both types of cultures with a relatively limited variability. During the process of fixation and staining, there is always a notable loss of free cells and clusters often conveying the impression that the growth activity is much less pronounced in the stained as compared with the living culture. This is especially noticeable in the Maximow cultures.

As previously explained, 3,4 it is possible, in endometrial tissue cultures, to distinguish two different growth patterns: one, representing a direct growth of the peripheral cells of the explant, in the form of rounded or spherical protrusions or of digital projections; and another, consisting in an outgrowth of cells rushing out of the explant in the form of a sheath of flattened cells, which, as they spread out, tend to grow considerably larger (Fig. 7-10). A similar outgrowth pattern can also be seen in roller tube cultures. In such cultures, the cells appear mostly in the form of aggregates, some of which may have a central core of densely packed cells (Fig. 11). The growth activity often appears to be more pronounced in the roller tube cultures probably because of the prevalence of a more lavorable nutritional environment.

Although the structural details of the cells are more clearly outlined in the fixed and stained cultures, several distinctive traits and patterns of the malignant cells may also be discerned in their living state. These can be seen chiefly in cultures which have not been contaminated with polymorphonuclears and other inflammatory cells. Many of the adenocarcinoma cells observed in vitro exhibit clistinctly abnormal features, which reveal their malignant nature, while others tend to display very atypical yet not conclusively malignant forms. In some of the malignant cases, particularly in their early stages, a granular material was sometimes noted within the cells of the explant (Fig. 8). One should also always expect to find in a tissue culture preparation a number of normal appearing cells, which, by virtue of their contrast, may, in a way, facilitate the detection and identification of the malignant cells.

The above described changes, as seen in the living cells, may often be sufficiently characteristic to permit the identification of their malignant nature. However, the cytologic as well as the histopathologic criteria of malignancy are usually more clearly defined in fixed and stained cultures and much more consistent with those generally accepted in any cytology or pathology laboratory. Of these criteria, the most important are those related to the structure of the nucleus. Karyomegaly, true hyper- 


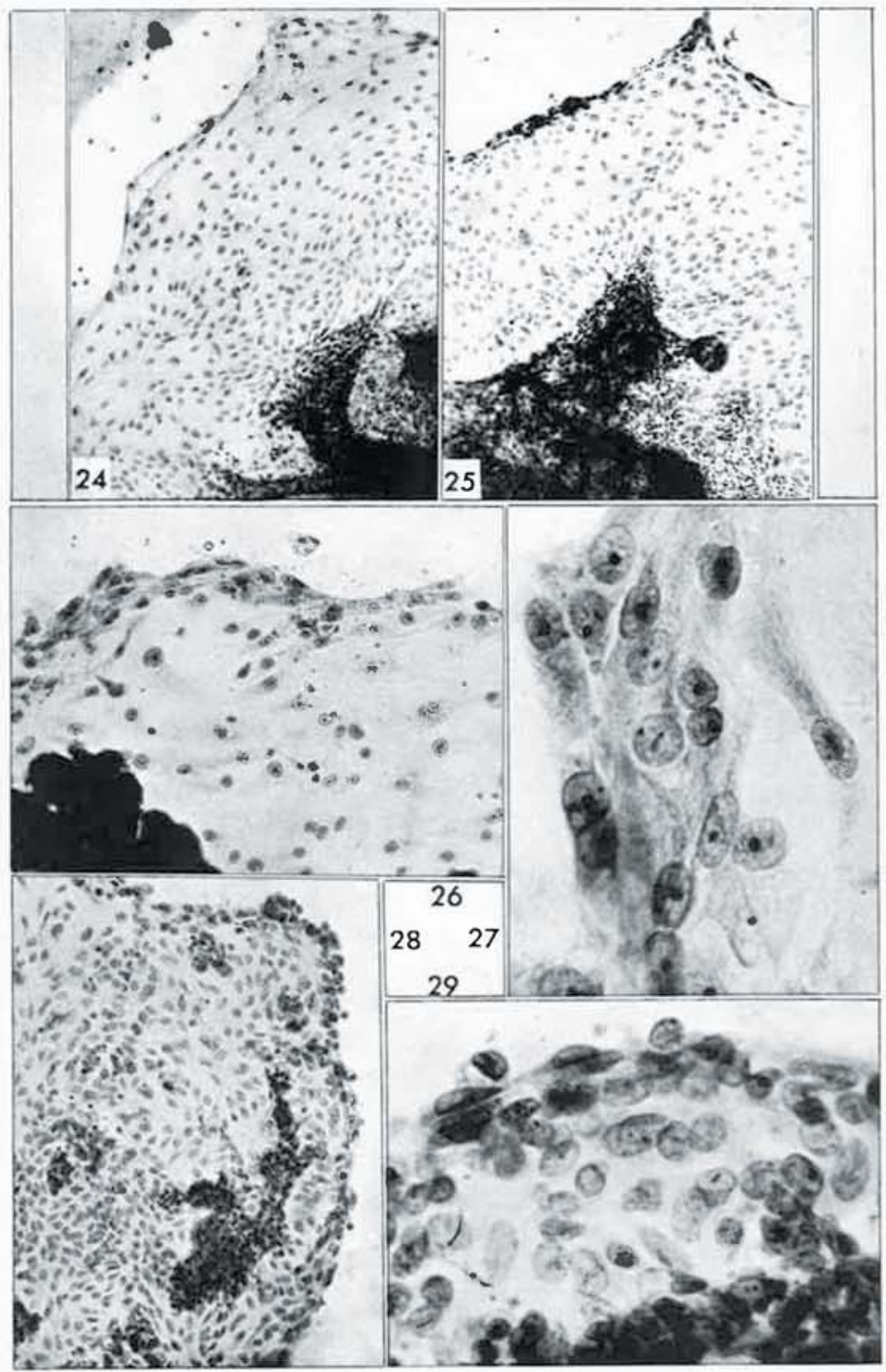

Fit. 24. H-day, normal endometrial tissue culture corresponding to the sth day of the menstrual cycle (x75). Note extrusion of epithelial cells from gland openings. Cells from the same cise at N465 magni. fication are illustrated in fication are illustrated in
Fig. 12. Fic. 25. 5-day tissuc culture of a papillary adenocarcinoma of the endometrium (x75). Note cxtrusion of malignant cells and a superficial zone of dense elongated cells. FIG. 26-27. 3-day tissuc culture of an adenocarcinoma of the endome trium (Fig. 26, x115. Fig. 27. $\times 465)$. Note formation of dense superficial zone. Fic. 25-29. 5-day roller tube tissue culture of an adenocarcinoma of the $\mathrm{cn}$ domentrium (Fig. 28, 115. Fig. 29. x465). Note formation of dense superficial zonc. Specimen ob. tained by endometrial as. piration.

chromasia due to excess of the chromatin content, abnormal nuclear forms, multinucleation, mitotic activity with aberrant types, amitotic divisions or nuclear buclding, atypical distribution or polarization of the chromatin and unusually large nucleoli are all criteria which have as much significance in this as in any other micro- scopic examination for cancer diagnosis. Some of the nuclear abnormalities most frequently observed in tissue culture preparations can be seen in Figures 13-15, 17-18. In adenocarcinomas of the endometrium, the presence of a single large nucleolus, as shown in Figures 13 and 15, is probably as valid as any other single criterion of 
malignancy. The above enumerated nuclear abnormalities of malignant cells are common to both adenocarcinomas and sarcomas of the endometrium.

The changes observed in the cytoplasm of the malignant cells in fixed and stained cultures, though not as pathognomonic as those seen in the nucleus, are quite often of definite diagnostic value. One of these changes is the atypical and often pronounced vacuolation of the malignant endometrial cells. In tissue fragments or celi
Ciusters, the vacuolation may be confined to the superficially located celis (Fig. 19) or may affect every cell of the explant (Fig. 20). An irregular architectural pattern and a loss of the boundaries between the cells are also among the criteria observed in sheaths, aggregates or clusters of malignant cells. In cases of adenoacanthoma, larger metaplastic cells with malignant features may be found in tissue cultures in addition to the adenocarcinoma cells.

The phenomenon of vacuolation appears
Fic. 30-31. 5-day tissuc cultures of adenocarcinoma of the endometrium (lig. 30, x115. Fig. 31, x 165. Note dense periph. eral zone. Fig. 32-33. 42hour roller tube tissue culture of peritoneal washings from a case of a papillary cystadenocarcinoma of the ovary (1iig. 32, x115. Fig. 33 , $\times 465)$. Same case as Fig. 21. Fir. 34.35. 9-day tissue culture of an adenocarcinoma of the endometrium demonstrating the streaming out of cells from the dense zone. (Fig. 34, x115. Fig. 35. $\times 465)$.

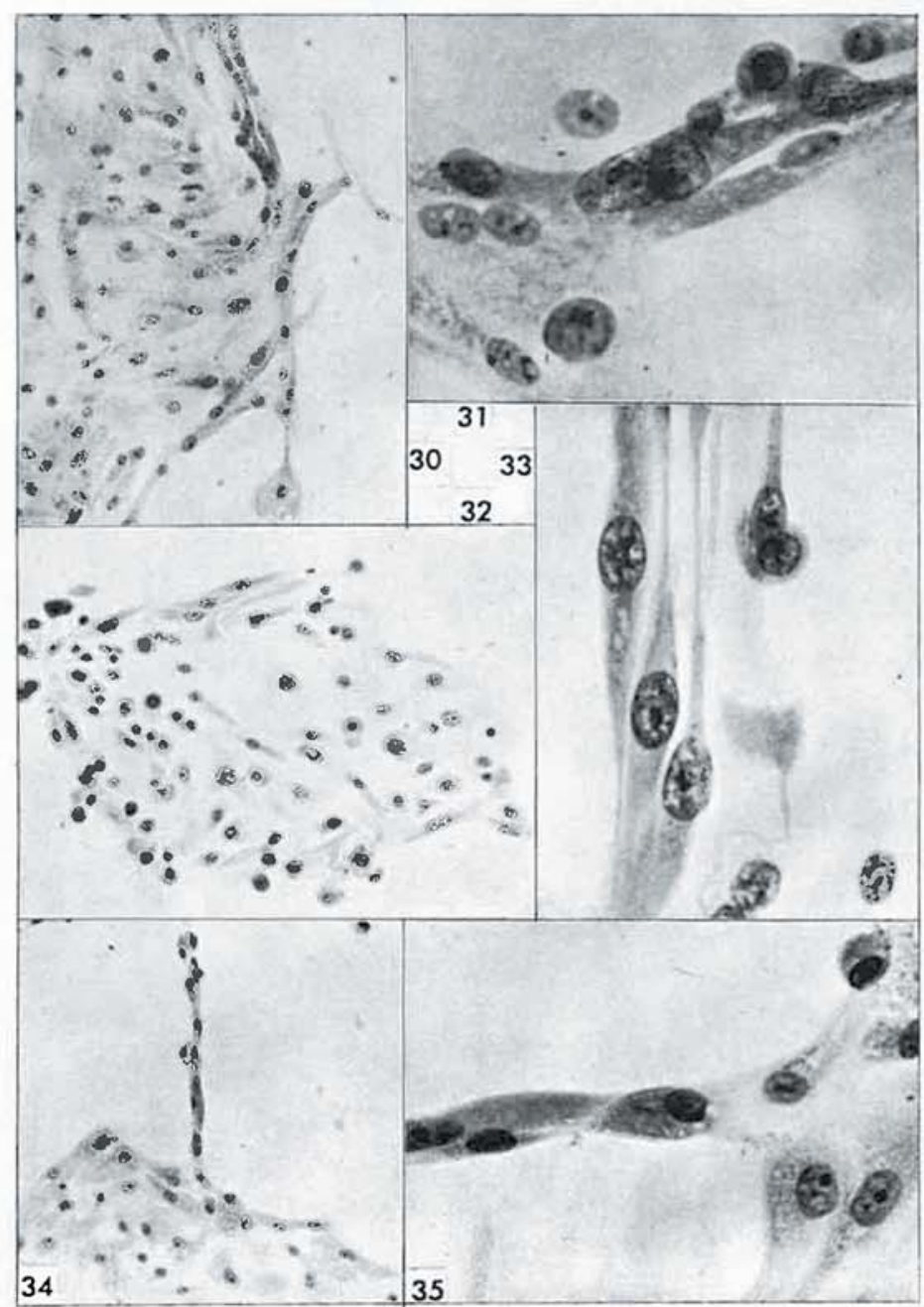

Papanicolaou's Studies on Endometrial Explants 


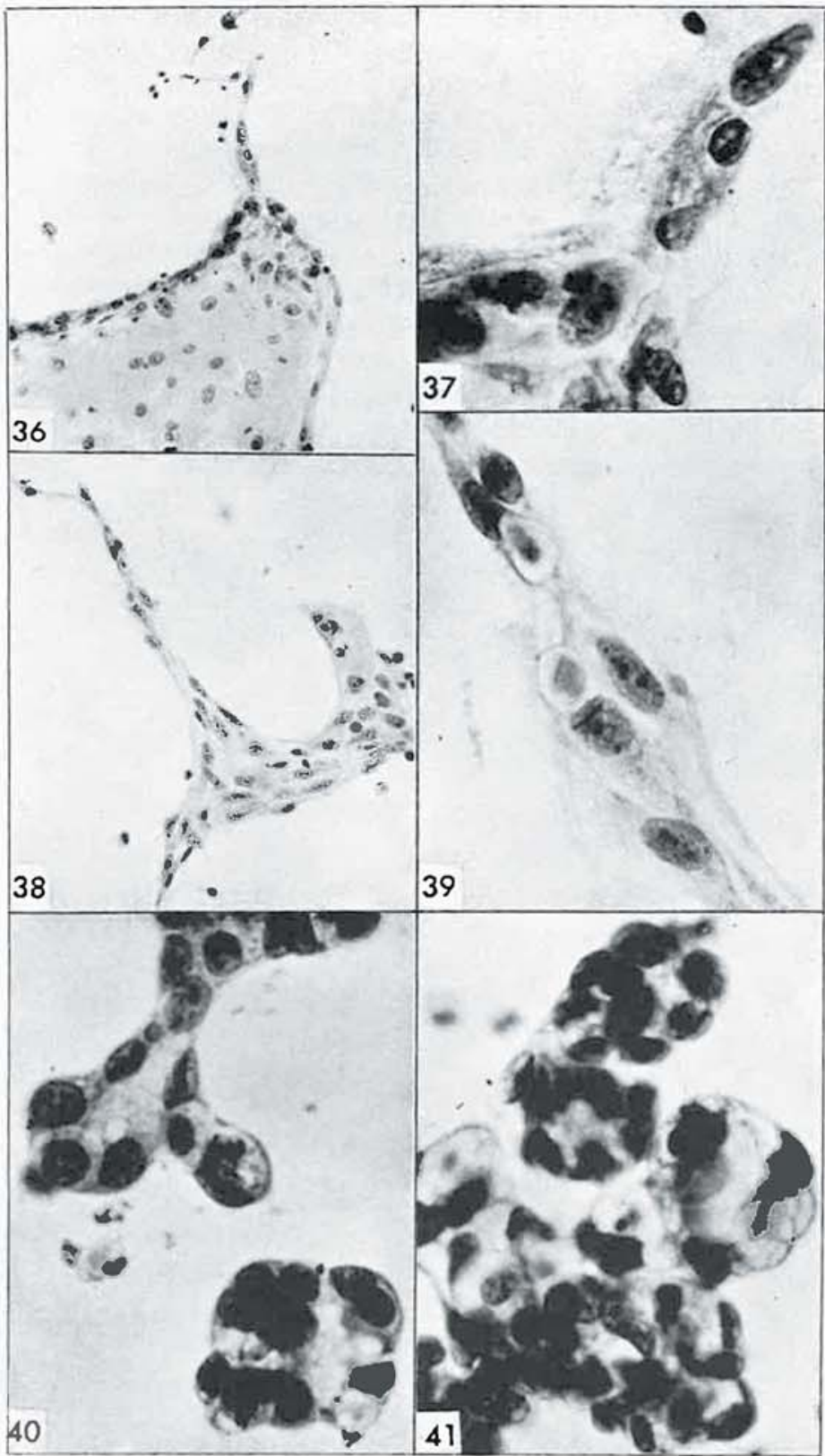

FIt: 36-37. 4-day tissuc culture of at adcnocarcinoma of the endometrium showing dense zone with outgrowing cells (Fig. 36 , x135. Fig. 37 , x540), Fic. 38-39. 72-hour tissue cul. ture of an adenocarcinoma of the endometrium illust:ating the same phenomenon as above (Fig. 38. x135. Fig. $39, \times 540$ ). Specimen oltained by endometrial aspiration. Fic. 40 72-hour roller tubc culture of ascitic fluid from it primary serous cystadenocarcinoma of the ovary with metastases to the omentum $(x 540)$. Fig. 41. t8-hour roller tube cuiture from the same case as Fig. 40 ( $\times 540)$.

to be closely associated with a high phagocytic activity, which is one of the characteristics of the malignant endometrial cells. The adenocarcinoma cells are rather indis- criminate in their phagocytic action and can engulf and digest other smaller cells, particularly degenerating blood cells, cellular detritus and various parasitic and 
bacterial forms (Fig. 22, 29). This unusually high phagocytic potentiality of the malignant endometrial cells may be considered as an accentuated expression of a fundamental biological property inherent in the normal epithelial cells of the endometrium, that of differentiating into true phagocytes. Cells liberated from the epithelium during the postmenstrual and early proliferative stages may thus assume the important function of cleansing the uterine cavity of the detritus accumulating after each menstrual exfoliative process. ${ }^{5}$ One should, of course, be sure not to interpret as malignant the smaller phagocytic cells which are rather frequently seen in tissue cultures, both malignant and nonmalignant. These cells have a normal appear-

Fic. 42, 16-hour roller tube culture from the same case as Fig. 41 ( $\mathrm{x}$ 465). Note the mitotic figure. F16. 43, 4-day tissue culture of adenocarcinoma of the enclometrium ( $\times 465)$. Note phagocytosis of smaller cells possibly mononuclears. Specimen obtaincd by endometrial aspiration. Fıc. 44. 3-day roller tuice tissue culture of ascitic fluid Irom a case of generalized carcinomatosis ( $\times 465)$ Note phagocytosis of inflammatory cells, also two normal fibroblasts. Fic. 45. 48-hour roller tube culture of ascitic fluid from the same case i!lustrated in Fig. 40-42 alsout one month following irradiation (x465). Note extreme vacuolation of three cells growing out of : cluster consisting of well preserved and apparenty viable cells. FIG. 16.5-daty roller tube tissue culture of ascitic fluid from a casc of metastatic papillary serous cystadenocarcinoma of the ovary showing very pronounced vacuolation and degeneration of cells approximately 4 months following irradiation ( $\mathrm{x}$ 465). Fic. 47. Same case and culuure as Fig 45. Note marked radiation effect on some of the cells (x465).

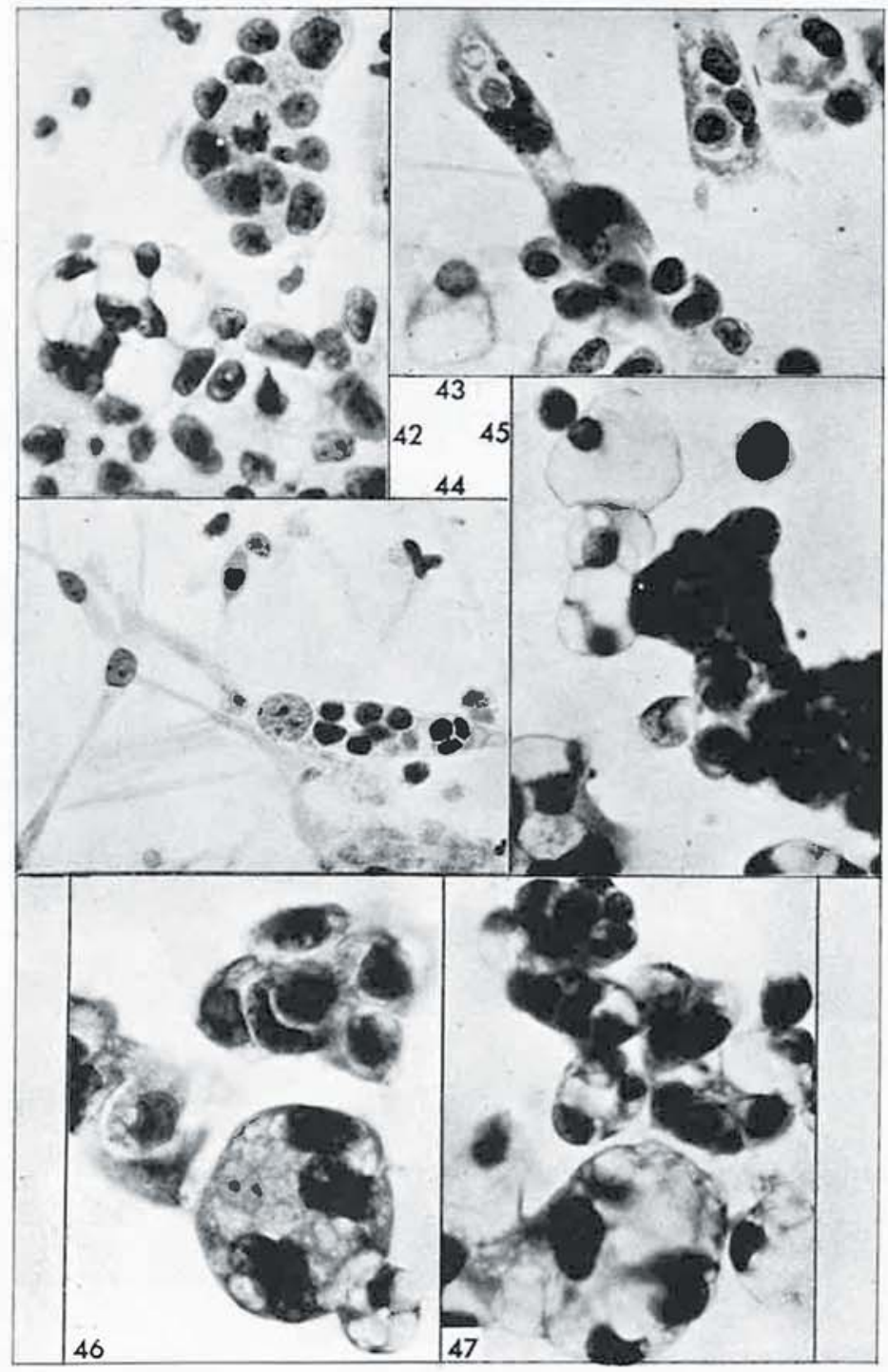




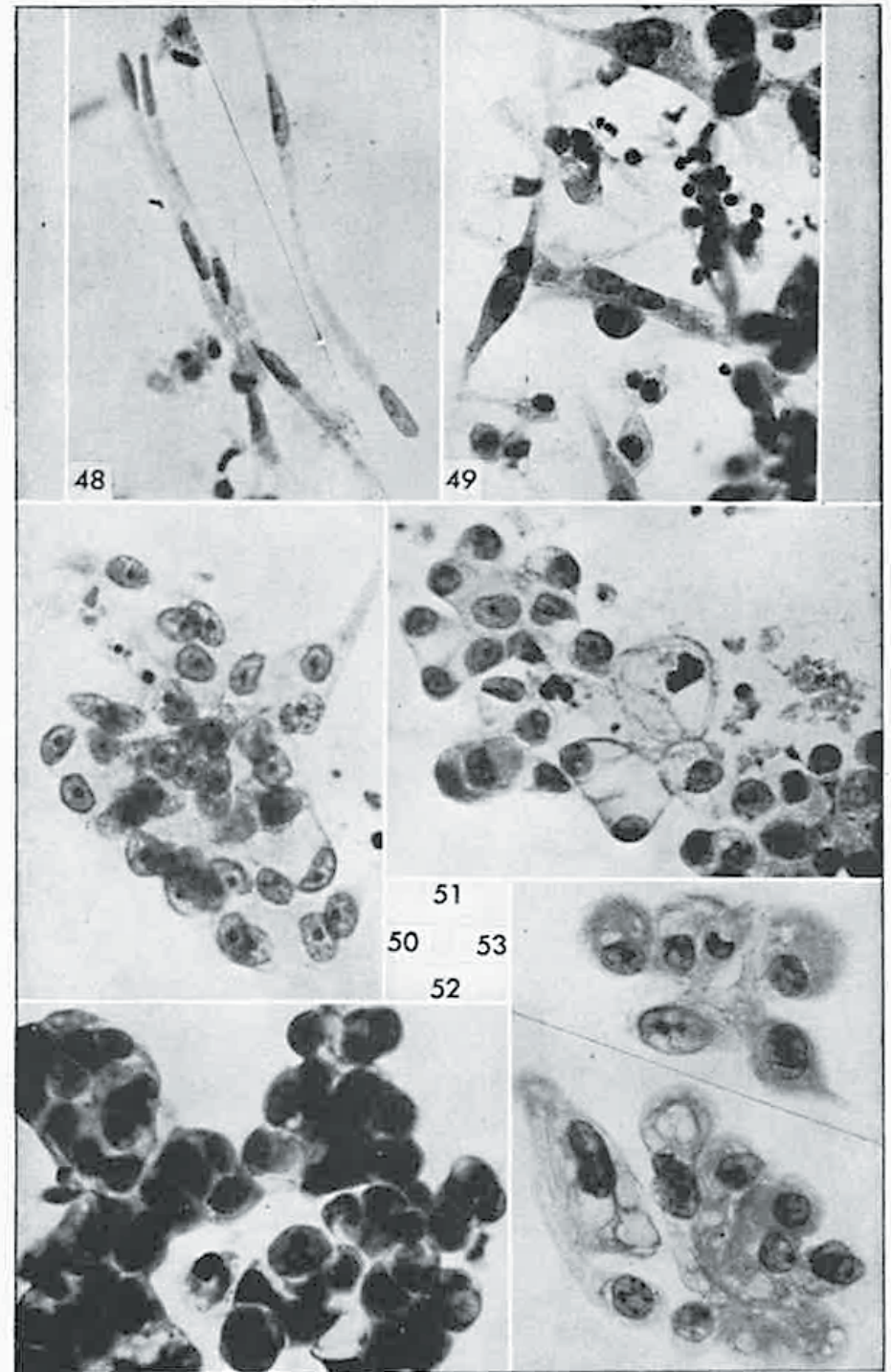

Fic. 48. 42-hour tissue culture from a specimen of a mixed mesodermal tu. mor obtained during operation (x465). The narrow elongated cells are interpreted as endothelial. Fic. 49. 16-hour roller tube tissue culture of a peritoneal washing demonstrating normal cells interpreted as fibroblasts intermixed with inflammatory cells (x465). Fic. 50-51. 16-hour and 4. day roller tube tissue cultures of endometrial as. piration fluid from a case of adenocarcinoma. This is one of the cases in which the tissue cul. ture findings have contributed to the diagnosis (x465). FIG. 52. Same case and culture as Fig. 45,47 showing a persistence of viable malignant cells after irradiation $(\mathrm{x} 465)$. Fig. 53. 6-day roller tube tissue culture of an irradiated adenocarcinoma of the endome. trium showing viable cells after a treatment of ap. proximately 7 days ( $\mathrm{x}$ 465). Specimen obtained by endometrial aspiration.

ance and normally phagocytose degenerating inflammatory cells, erythrocytes as well as bacteria and parasites.

Actively growing explants from a benign polypoid or papillary growth often assume a pattern greatly resembling that of an endometrial adenocarcinoma (Fig. 4-6). However, despite the close similarities in their growth patterns, the benign and malignant cells are apparently endowed with different potentialities for differentiation, which determine their final configuration into one or the other type. The behavior of these two cell types in tissue cultures indicates that each of the two factors, the one stimulating growth and the other re- 
sponsible for malignancy, though generally combined in their action, actually represent two distinct entities.

The structural details and the differential characteristics of both malignant and non-malignant cells can be more clearly outlined in the sheaths formed by the cells growing out of the tissue. These cells are, as a rule, flattened, enlarged and more transparent than the densely packed cells within the explant. In such sheaths, malignant cells, if present, can be more easily identified by their aberrant features (Fig. 13-15 and 17-18).

Sheath cells with somewhat atypical structural characteristics may occasionally be seen in non-malignant cultures, chiefly in cases of hyperplasia in which a certain variation in the size of the nuclei (anisokaryosis) is not an uncommon occurrence. The structure of the individual cells in such cases is, however, essentially normal.

What enhances the diagnostic value of the tissue culture method is that the individual characteristics of the malignant cells and their growth patterns, as seen in fixed and stained cultures, are, in many instances, very clearly defined. A conclusive and definitely positive diagnosis, equivalent to a Class $\mathrm{V}$ cytologic evaluation is thus possible in a fair number of cases. In addition to the above described structural abnormalities, there may also be a characteristic elongation and densification of the cells. This change is more noticeable in the peripheral cells, which then tend to spread over the surface of the explant or aggregate in the form of a narrow compact zone (Fig. 25-33). In certain areas, some of these superficial elongated cells stream out in a perpendicular fashion suggesting a migratory activity (Fig. 34-39). A variety of other abnormal features as well as an intense phagocytic activity may also be often noted in such cells (Fig. 39).
Cytology of Tissue Cultures from Pleural and Peritoneal Effusions

The abnormal features of malignant cells found in tissue cultures from aspirations of pleural or peritoneal fluid or washings in cases of metastatic adenocarcinoma show great resemblance to those described for the adenocarcinomas of the endometrium (Fig. 13-15 and 17-18). The cytologic criteria by which the presence of a malignant process can be ascertained are, therefore, essentially the same.

In general, both the proliferative and growth activity of the malignant cells are very marked in tissue cultures from pleural and peritoneal fluid or washing specimens. Mitotic and amitotic division or budding are not uncommon in such cultures. One can also find a variety of aberrant and bizarre cell forms and a high phagocyic activity (Fig. 40-44). Since pleural or peritoneal fluid is in itself an excellent culture medium, it may be used as such with very good results either alone or in combination with equal parts of the regular medium. Extreme vacuolation, as already mentioned, is known to be one of the most characteristic postradiation changes (Fig. 45-47).

Elongated malignant cells, when single, can oftentimes be identified with great difficulty since effusion tissue cultures, often contain large numbers of fibroblasts and endothelial cells. The endothelial cells can be more easily recognized by their slender form and their tendency to arrange themselves in a linear formation (Fig. 48), whereas the fibroblasts present a more difficult diagnostic problem due to their great variability in size and form (Fig. 49). When grouped in aggregates or clusters, the malignant cells can be identified with much higher accuracy, equalling that of the malignant endometrial cells. 


\section{Discussion}

The value of tissue culture in the diagnosis of malignant disease was advocated by a number of investigators, who used this method in the study of pleural and peritoneal effusions. Coman ${ }^{2}$ states that "cells from carcinomas and sarcomas grew vigorously, thereby indicating that such cells remain viable and capable of proliferation after floating in pleural or peritoneal fluids if given a satisfactory surface to which they may become attached." Coman used the roller tube technic. $\mathrm{He}$ concludes that "the culture of cells from pleural and ascitic fluids can in some instances at least, be of diagnostic aid." Similar conclusions were reached by Sano and Bello ${ }^{6}$ who found that "cells from human body fluids have different growth patterns in tissue culture which may be of diagnostic value, especially in those cases in which other methods have failed to establish a diagnosis." In a later report on his observations in a study of a new series of pleural effusions in correlation with "cell block and Papanicolaou smear" studies, $\mathrm{Sano}^{7}$ states that "Kinetic pathology, or tissue culture as applied to pathology has been shown to be a valuable diagnostic tool and an adjunct to cell block and smear studies, but not a substitute for these."

Bencze $^{1}$ summarizes as follows his investigations on the use of tissue culture in the diagnosis of cancer in exudates, made with the aid of a special technic: "Diagnostic tissue cultures of thoracic and abdominal exudates were carried out in 30 cases. The tissue culture diagnosis was in agreement with the clinical diagnosis in 23 of the cases; in 6 cases the correct diagnosis was given only by the tissue culture. In one instance the autopsy diagnosis differed from that of the tissue culture. In the tissue culture, the tumor cells form large cell groups which are of value diagnostically." (Translation from German.)
The results obtained by these investigators are in agreement with our observations. The tissue culture is indeed of definite value in the diagnosis of neoplasms developing within the pleural or peritoneal cavities, more specifically of those metastasizing from primary carcinomas of the ovary. In the light of our investigations, the same statement can also be made with regard to the utilization of the tissue culture method in the diagnosis of adenocarcinoma of the endometrium. Its application in this organ is bound to be of immense value not only in establishing the diagnosis of intra-uterine cancer in some of the obscure cases but also in its early detection which is still difficult with the currently used diagnostic procedures.

Exfoliative Cytology, which proved to be of major importance in the diagnosis and early detection of cancer of the uterine cervix, has unfortunately, not been equally satisfactory in the detection of intra-uterine malignancies. Routine vaginal and cervical and even endometrial smears often fail to provide sufficiently conclusive evidence in cases in which the presence of an intrauterine neoplasm is suspected. In these cases, the addition of a tissue culture to the routine cytologic examination would probably be of great help in clarifying the diagnosis. The two methods actually complement one another. The smear technic possesses the advantage of general applicability, which makes it an ideal routine screening and diagnostic procedure. On the other hand, a tissue culture preparation may, in some instances, add more conclusive evidence permitting a definitely positive Class V evaluation. This is more important in early malignancy in which the diagnosis is always more difficult due to the lack of clean-cut and strictly objective cytologic and histopathologic criteria for identifying the earliest manifestations of endometrial adenocarcinoma. In several of the early or ambiguous cases 
of adenocarcinoma which have been included in this study, the tissue culture has provided the primary or the most conclusive evidence. In two instances a surgical procedure was decided upon largely on the basis of the tissue culture findings.

The evaluation of the effect of irradiation is another useful and very promising application of the tissue culture method. Exfoliative cytology has already been applied on a relatively large scale in the study of postradiation changes and in many instances has provided significant information regarding the effectiveness of radiation therapy and the evidence of a residual extension or recurrence. However, the usefulness of exfoliative cytology in evaluating structural changes in irradiated cells is limited by the fact that, in most instances, it is difficult to decide as to the viability of these cells and, therefore, as to the persistence of an active growth. Such information, may, of course, be provided by the examination of cells in vitro (Fig. 52, 53).

Adequate growth for a diagnostic evaluation of a tissue culture can often be obtained within 16 to 24 hours (Fig. 21, 22, 42, 50 ), although older cultures exhibiting more advanced stages of growth are, in general, more conclusive, particularly in the doubtful cases. Occasionally, the malignant cells appear for the first time in cultures several days old. Negative findings should, therefore, never be interpreted as definitely conclusive.

Endometrial cells, both normal and malignant, were found to be viable in cultures from aspiration specimens, which have been kept in refrigeration for 24 to 48 hours and, in cases of ascites for three to four days after tapping. In a number of effusion cultures continued growth was noted for a period of 25 to 30 days without change of the medium.

A rather important point with regard to the use of tissue culture as a routine diagnostic procedure, is that a simple aspirate of endometrial fluid is, in many instances, sufficient to secure adequate cytologic material for a tissue culture study. Curettage material, of course, is apt to be more copious but implies an operative procedure, which is not always advisable or feasible.

Although fully realizing the various difficulties, technical and others, associated with the wider use of tissue culture in the diagnosis of cancer, polypoid hyperplasia and other pathologic conditions of the endometrium, we feel that the continued advancement in the scientific and technical aspects of this method and its proven diagnostic reliability make it not only very desirable but well-nigh indispensable as an adjunct to other diagnostic procedures. The fact that, in several instances, a definitive diagnosis may depend largely on the utilization of this method, fully justifies its incorporation in the armamentarium of the well equipped diagnostic pathology or cytology laboratory-not to mention its immense value in the investigation of problems not only of clinical but also of fundamental significance and import.

\section{Conclusions}

1. The value of the tissue culture method in cancer diagnosis has been investigated in 50 cases of pathologically proven adenocarcinoma of the endometrium and 25 of peritoneal and pleural effusions or washings from proven adenocarcinoma of the ovary.

2. The material consisted of human endometrial tissue obtained by aspiration, curettage or hysterectomy and of peritoneal fluid or washings aspirated during surgery.

3. Two technics were used for the preparation of cultures, the Maximow and the roller tube. The Maximow culture proved to be of greater value in the over-all study of the malignant endometrial cytology and of the prevailing growth patterns. The main advantage of the roller tube technic
Papanicolaou's Studies on Endometrial Explants
Acta Cytologica 2017;61:281-298

DOI: $10.1159 / 000475980$ 
has been its greater adaptability as a cliagnostic procedure.

4. Observations on the morphologic characteristics and growth activity of the cells were made in living as well as in fixed and stained preparations. Malignant cells have, as a rule, exhibited very active growth and an intense phagocytic activity.

5. The cytologic criteria of malignancy were found to be comparable to those generally accepted in the pathology and cytology laboratories. However, the high growth activity of the malignant cells in vitro results in the appearance of a variety of characteristic patterns, which provide additional criteria for a more conclusive diagnosis.

6. The tissue culture method can be most profitably used in obscure diagnostic cases in which the presence of a malignant neoplasm could not be established by other diagnostic procedures. It also proved to be of great value in the detection of early cancer and in the evaluation of postradia- tion changes by ascertaining the viability of malignant cells, which have been exposed to irracliation.

7. Since growth, particularly in the roller tube cultures, may be observed within 16 to 24 hours and simple aspiration specimens can be obtained with relative ease in the majority of cases, it is felt that the tissue culture method may be employed, at least in certain organs, to great advantage as an adjunct to other diagnostic procedures.

\section{Bibliography}

1. Bencze, G.: Zeitschr. f. Krebsforschung. 63: 262, 1960.

2. Coman, R. C.: Cancer Res. 3: 526, 1943.

3. Papanicolaou, G. N. and F. V. Maddi: Am. J. Obst. \& Gyn. 76: 601, 1958.

4. Papanicolaou, G. N. and F. V. Maddi: Am. J. Obst. \& Gyn. 78: 156, 1959

5. Papanicolaou, G. N.: Fertil. and Steril. 4:472, 1953.

6. Sano, M. E. and C. T. Bello: Am. J. Surg. 81: $515,1951$.

7. Sano, M. E.: Surg., Gyn. \& Obst. 97: 665, 1953.

\section{References}

1 Papanicolaou GN, Maddi FV: Diagnostic value of cells of endometrial and ovarian origin in human tissue cultures. Acta Cytol 1961;5: $1-16$.

2 Carmichael DE: The Pap Smear: Life of George N. Papanicolaou. Springfield, Thomas, 1973.

3 Papanicoloau GN: Observations on the origin and specific function of the histiocytes in the female genital tract. Fertil Steril 1953;4:472478.

4 Papanicolaou GN, Maddi FV: Observations on the behavior of human endometrial cells in tissue culture. Am J Obstet Gynecol 1958;76: 601-618.
5 Papanicolaou GN, Maddi FV: Further observations on the behavior of human endometrial cells in tissue culture. Am J Obstet Gynecol 1959;78:156-173.

6 Maddi FV, Papanicolaou GN: Diagnostic significance of ciliated cells in human endometrial tissue cultures. Am J Obstet Gynecol 1961;82:99-101.

7 Papanicolaou GN, Traut HF: The diagnostic value of vaginal smears in carcinoma of the uterus. Am J Obstet Gynecol 1941;42:193206.
8 Papanicolaou GN, Traut HF: Diagnosis of Uterine Cancer By The Vaginal Smear. New York, The Commonwealth Fund, 1943.

9 Kipp BR, Medeiros F, Campion MB, Distad MB, Peterson LM, Keeney GL, Halling KC, Clayton AC: Direct uterine sampling with the Tao brush sampler using a liquid-based preparation method for the detection of endometrial cancer and atypical hyperplasia. Cancer Cytopathol 2008;114: 228-235. 